\title{
A missão é divulgar
}

A missão da $R B M E$ é "Disseminar a produção cientifica nas áreas de ciências do exercício e do esporte, através da publicação de resultados de pesquisas originais e de outras formas de divulgação científica que contribuam para o conhecimento fundamental e aplicado em atividade física, exercício e esporte no âmbito das ciências biológicas e da medicina". A palavra-chave é "disseminar". Temos trabalhado nesse sentido conquistando a indexação na SciELO (www.scielo.br), oferecendo acesso a domínio próprio (www.rbme.org.br) e incluindo a $R B M E$ em vários portais de busca qualificada como o portal Free Medical Journals (http://www.freemedicaljournals.com/). Mas "disseminar" não pode ser uma atitude passiva; temos que ser pró-ativos na divulgação das publicações da $R B M E$. Por essa razão, convidamos a todos para incluir em suas rotinas profissionais a divulgação da $R B M E$. Nossa experiência pessoal mostra que muitas pessoas ainda não conhecem nosso periódico, mas se tornam leitores assíduos tão logo fazem contato com os artigos e demais conteúdos publicados. Sugerimos aos autores que, além de naturalmente citarem suas próprias referências de publicações na $R B M E$, estimulem seus pares a consultarem os diversos fascículos da $R B M E$ em suas buscas bibliográficas. Aos demais leitores e colaboradores que ainda não participam como autores da $R B M E$, sugerimos que transmitam suas experiências de utilização da $R B M E$ como fonte de informação científica. $\mathrm{O}$ aumento do público interessado na $R B M E$ é um processo necessário para que a nossa missão se desenvolva de forma plena. Contamos com todos!

Prof. Dr. Antonio Claudio Lucas da Nóbrega Editor-chefe 